\title{
FIRST MAJOR MILITARY INCURSIONS IN SARAWAK, SABAH AND PENINSULAR MALAYSIA DURING INDONESIA- MALAYSIA CONFRONTATION: PERSPECTIVES OF SELECTED MALAYSIAN ENGLISH-LANGUAGE NEWSPAPERS
}

\author{
${ }^{1}$ Chong Wu Ling* \& 2 Sivachandralingam Sundara Raja \\ ${ }^{1}$ Department of Southeast Asian Studies, \\ University of Malaya, Kuala Lumpur, Malaysia \\ ${ }^{2}$ Department of History, University of Malaya, Kuala Lumpur, Malaysia \\ ( ${ }^{*}$ First author) \\ (chong.wu.ling@um.edu.my, siva@um.edu.my) \\ DOI: https://doi.org/10.22452/jati.vol23no2.1
}

\begin{abstract}
This study examines how the first major military incursions in Sarawak, Sabah and Peninsular Malaysia during the Indonesia-Malaysia Confrontation in 19631964 were reported in three selected Malaysian English-language newspapers. These newspapers are The Straits Times, published in Singapore, North Borneo News and Sabah Times (hereafter Sabah Times), published in Sabah, and The Sarawak Tribune, published in Sarawak. This study employed a qualitative content analysis of the newspapers to examine their coverage on the issue. The findings show that The Straits Times generally provided the widest coverage on the first major military incursions in Sarawak and Peninsular Malaysia. Sabah Times, on the other hand, provided the most extensive news coverage on the military raid on Sabah. This was probably due to limited manpower and financial strength of the two newspapers and not the lack of concern of both newspapers and their readers of the situation in the affected localities.
\end{abstract}

Keywords: Indonesia-Malaysia Confrontation, military incursions, The Straits Times, North Borneo News and Sabah Times, The Sarawak Tribune, news media coverage 


\section{Introduction}

This study examines how the first major military incursions in Sarawak, Sabah and Peninsular Malaysia during the Indonesia-Malaysia Confrontation in 19631964 were reported in three selected Malaysian English-language newspapers. Although the scope of this study also covers the period before the official formation of the Federation of Malaysia on 16 September 1963, for simplification, this paper refers to the three selected English-language newspapers as 'Malaysian' English-language newspapers. The IndonesiaMalaysia Confrontation was Indonesia's political and armed opposition against the creation of the Federation of Malaysia in 1963. The Federation comprised of the Federation of Malaya (present-day Peninsular Malaysia), Singapore and the British colonies in North Borneo, i.e., Sabah and Sarawak. The proposal for the Federation was first announced in May 1961. Although Indonesia initially did not object to the proposal, it began to oppose the proposal after the outbreak of the Brunei revolt in 1962 (Mackie, 1974) (For more details of the Brunei revolt, see Harun Abdul Majid [2007]). The then president of Indonesia, Sukarno, perceived the formation of Malaysia as a manifestation of British neocolonialism, especially because Britain would continue to have military bases in Malaya and Singapore. Subandrio, the foreign minister of Indonesia, even announced on 20 January 1963 that Indonesia would execute a policy of confrontation against Malaysia (Nik Anuar Nik Mahmud, 2009, p. 75).

The first series of military incursions took place in Tebedu, Sarawak on 12 April 1963. Although Malaysia was still not yet officially formed when the armed raid happened, the Malaysian government perceived the raid as the first military incursion on Eastern Malaysia launched by Indonesians. This can be seen from the categorisation of the raid as the first land incursion on Eastern Malaysia in an official report on the Confrontation entitled Indonesian aggression against Malaysia, Vol. 1 (1965) published by the government. During the raid, the Indonesian armed forces breached and attacked a police station at Tebedu, which was about three miles from the border between Sarawak and Indonesia (Indonesian aggression against Malaysia, Vol. 1 1965, p. 1). Subsequent attacks were made on Sabah on 29 December 1963 and Peninsular Malaysia on 17 August 1964 (Indonesian aggression against Malaysia, Vol. 1, 1965, pp. 8-11; Indonesian aggression against Malaysia, Vol. 2, 1965, p. 2). However, most of the military incursions conducted by Indonesia took place in the border area between Sarawak and Indonesia.

During the height of the Confrontation, Singapore was ejected from the Federation of Malaysia on 9 August 1965 due to ongoing political deadlock 
between the ruling political parties in Malaysia and the People's Action Party (PAP) of Singapore. The Confrontation only ended in 1966 after the military takeover of Indonesia in which General Suharto replaced Sukarno. A peace treaty was eventually signed on 11 August 1966 ending hostilities between Indonesia and Malaysia (Nik Anuar Nik Mahmud, 2009, pp. 238-239).

Since space limitation does not allow for a comprehensive analysis of news coverage by the three selected English-language on the Confrontation from 1963 until 1966, this paper focuses on their coverage and perspectives on the first major military incursions in Sarawak, Sabah and Peninsular Malaysia during the period. It is also based on the understanding that any military incursion that took place for the first time in any place would have attracted considerable attention from the public and media. A qualitative content analysis of the selected newspapers was employed to examine their coverage and perspectives on the issue. These newspapers are The Straits Times, published in Singapore (and later in Peninsular Malaysia after the separation of Singapore from Malaysia), North Borneo News and Sabah Times, published in Sabah, and The Sarawak Tribune, published in Sarawak. This study also compares the perspectives of these newspapers on the first major military incursions in the three places. The following sections explain the background of these newspapers.

\section{The Straits Times}

The Straits Times was founded and launched in 1895 by Catchick Moses, an American businessman, and Robert Carr Woods, an English journalist, in Singapore. The newspaper focused on local issues in Singapore and Malaya. The press later became a public limited company in 1950 ("The Straits Times", 2016).

The Straits Times is widely acknowledged as "the most widely read newspaper in Singapore" ("The Straits Times", 2016). When Singapore was part of Malaysia from 16 September 1963 to 9 August 1965, the newspaper also "had widespread circulation and influence in Malaysia" ("The Straits Times", 2016). However, it was not until 1974 that a separate Malaysian version of the newspaper known as the New Straits Times was established. The Singapore version remained to be known as The Straits Times ("Corporate history", n.d.).

The Straits Times was already a well-established newspaper in the 1960s, including the period that this paper covers. The press was able to hire many journalists and hence the newspaper was published every day, including during weekends and public holidays. The Straits Times was also a thick newspaper, as its total pages were usually 20. 


\section{The Sarawak Tribune}

The Sarawak Tribune is the oldest English-language newspaper in Sarawak. It was established by a group of Teochew Chinese businessmen and former school teachers in Sarawak after the Second World War in 1945 (Thien, 2006; "Tribune is the oldest paper in Sarawak", 2006). The newspaper was initially known as the Sarawak Times. It was later renamed as The Sarawak Tribune, which became the largest operating newspaper in the state (Thien, 2004). However, The Sarawak Tribune was suspended by the government in 2006 following the publication of the Jyllands-Posten Muhammad cartoons ("Sarawak Tribune suspended indefinitely", 2006) (For more information on the Jyllands-Posten Muhammad cartoons controversy, see Anderson [2006]). It was only allowed to resume operation in 2010 ("S'wak oldest daily returns to newsstand after ban", 2010).

In the 1960s, there was no publication of The Sarawak Tribune on Sundays and public holidays or during major Christian festivals since Sarawak had a large population of Christians. For instance, in 1963, the newspaper was not published from 13 to 15 April during two major Christian festivals, i.e. Good Friday and Easter fell, falling on 12 and 14 April respectively. In addition, the total pages of The Sarawak Tribune were usually 8, 10 or 12, making the newspaper much thinner than The Straits Times. This indicates that The Sarawak Tribune was not as well-established as The Straits Times and was not able to hire many journalists to produce news reports every day.

\section{North Borneo News and Sabah Times}

North Borneo News and Sabah Times (hereafter Sabah Times) were initially known as Sabah Times when it was established in 1949 by Donald Stephens, who worked as a reporter in the North Borneo News, another English-language newspaper in Sabah. Donald Stephens later became the first chief minister of Sabah when it became an independent state (formerly under the United Kingdom) ("Profile", n.d.). Sabah Times was later merged with the North Borneo News in 1954 and renamed the North Borneo News and Sabah Times (Barlocco, 2014, p. 46).

In the 1960s, Sabah Times was very similar to The Sarawak Tribune in terms of financial and manpower strength. It was not published every Sunday and during public holidays or major Christian festivals because Sabah also had a large population of Christians. However, during the Good Friday and Easter holidays in 1963, Sabah Times only took a break on 13 and 14 April, and resumed publication on 15 April, unlike The Sarawak Tribune which only resumed publication on 16 April. In addition, Sabah Times was also a thin 
newspaper like The Sarawak Tribune because its total pages were usually 8,10 or 12 as well. This shows that both newspapers were not as well-established as The Straits Times.

Sabah Times ceased publication in 1995 and was revived as the New Sabah Times in 1998 ("Profile", n.d.).

\section{Literature Review}

Scholarly works that discuss the origins and background of the Confrontation include those of J. A. C. Mackie (1974), Matthew Jones (2002), Nik Anuar Nik Mahmud (2009), and Greg Poulgrain (2014). Mackie (1974) focuses on the domestic political background of Malaysia and Indonesia that played a crucial role in the Confrontation. Jones (2002) looks into the international politics behind the creation of the Federation of Malaysia and the emergence of the Confrontation. Nik Anuar Nik Mahmud (2009) examines the role of the Malaysian government in dealing with the Confrontation. Poulgrain (2014) analyses the origins of the 1962 Brunei Revolt and the domestic politics of Indonesia that generated the Confrontation in 1963. However, none of these works deals with the perspectives of Malaysian newspapers on the Confrontation. It is important to study how the newspapers reported and commented on the issue. This is crucial as the contents of the newspapers often reflected the readers' point of view and concerns. Newspapers usually report what the readers are interested to read. By looking into the coverage of Malaysian newspapers on the Confrontation, one could also have a firmer understanding of the readers' views and concerns on the issue.

To the knowledge of the researchers, there is presently only one unpublished undergraduate academic exercise that analyses news coverage of the Confrontation. It focuses on the Utusan Melayu, a major Malay-language newspaper in Malaysia from 1939 to 1967. Written by Muhammad Fauzi Mohd. Rosidi, the title of the academic exercise is Utusan Melayu: Kajian terhadap isu Konfrontasi Malaysia-Indonesia, 1963-1966 (Utusan Melayu: A study on the issue of Malaysia-Indonesia Confrontation, 1963-1966). According to the author, Utusan Melayu highlighted important details of the Confrontation, including the views and actions of the Malay Rulers, cabinet members, regional state chief ministers, and the grassroots.

Nevertheless, it is equally important to look into how the Englishlanguage newspapers in the Peninsular Malaysia, Sabah and Sarawak reported and commented on the issue since they had different groups of readers. In the 1960s, readers of English-language newspapers in Malaysia generally belonged 
to the English-educated middle and upper classes from different ethnic groups. In order to fill the lacuna of this area, this study not only examines the perspectives of selected Malaysian English-language newspapers on the first major military incursions in different localities during the Confrontation but also compares the perspectives of these newspapers.

\section{Research Methods}

The methods used in this study are the library and archival research as well as qualitative content analysis. Library and archival research was conducted by consulting primary and secondary sources at the Central Library and Za'ba Memorial Library, University of Malaya; the State Archives of Sabah, Kota Kinabalu; the Baillieu Library, University of Melbourne; the Central Library, National University of Singapore (NUS); and the National Library of Singapore. The primary sources include news and commentary articles on the first major military incursions by the Indonesians in Sarawak, Sabah and Peninsular Malaysia in The Straits Times, The Sarawak Tribune and Sabah Times, and official publications on the Confrontation released by the Malaysian government. The secondary sources include books, journal articles and academic writings regarding the Confrontation. This study adopts a qualitative content analysis method to analyse how the selected newspapers reported and how much they focused on the first major military incursions in Sarawak, Sabah and Peninsular Malaysia.

\section{Summary of Selected News Articles in The Straits Time, The Sarawak Tribune, and Sabah Times}

Table 1 shows the number of selected news articles in the three Englishlanguage newspapers. These news articles are related to the first major military incursions in Sarawak, Sabah and Peninsular Malaysia. Our search period was from 13-27 April 1963 for the first major military incursion in Sarawak, 31 December 1963-30 January 1964 for the first major military incursion in Sabah, and 18-27 August 1964 for the first major military incursion in Peninsular Malaysia. The news articles include ordinary news reports, special reports (i.e., news reports written by correspondents or on-the-scene reporters), editorials, commentaries or letters to the editor, editorials cited from the foreign press, and photo(s) with captions. 
Table 1. Number of Selected News Articles Published in the Three EnglishLanguage Newspapers

\begin{tabular}{|l|c|c|c|}
\hline \multicolumn{1}{|c|}{ Issue } & $\begin{array}{c}\text { The } \\
\text { Straits } \\
\text { Times }\end{array}$ & $\begin{array}{c}\text { The } \\
\text { Sarawak } \\
\text { Tribune }\end{array}$ & $\begin{array}{c}\text { Sabah } \\
\text { Times }\end{array}$ \\
\hline $\begin{array}{l}\text { The first major military incursion in Sarawak, } \\
\text { April 12, 1963 (Period of newspaper articles } \\
\text { studied: 13-27 April 1963) }\end{array}$ & 5 & 3 & 2 \\
\hline $\begin{array}{l}\text { The first major military incursion in Sabah, } \\
\text { December 29, 1963 (Period of newspaper articles } \\
\text { studied: 31 December 1963-30 January 1964) }\end{array}$ & 18 & 4 & 19 \\
\hline $\begin{array}{l}\text { The first major military incursion in Peninsular } \\
\text { Malaysia, August 17, 1964 (Period of newspaper } \\
\text { articles studied: 18-27 August 1964) }\end{array}$ & 32 & 11 & 10 \\
\hline
\end{tabular}

\section{Findings and Discussion}

First Major Military Incursion in Sarawak, 12 April 1963

As noted in Indonesian aggression against Malaysia, Vol 1 (1965, p. 1), the first series of military incursions in Sarawak took place when a group of "armed men in uniform attacked a Police Station [sic] at Tebedu in Sarawak, three miles from the Indonesian border" on 12 April 1963. The raid, which coincided Good Friday, resulted in the death of a corporal and the injury of two soldiers.

Table 2. Number of Selected News Articles Published on the First Major Military Incursion in Sarawak

\begin{tabular}{|l|c|c|c|}
\hline \multicolumn{1}{|c|}{ Type of News Articles } & $\begin{array}{c}\text { The } \\
\text { Straits } \\
\text { Times }\end{array}$ & $\begin{array}{c}\text { The } \\
\text { Sarawak } \\
\text { Tribune }\end{array}$ & $\begin{array}{c}\text { Sabah } \\
\text { Times }\end{array}$ \\
\hline Ordinary news report & 5 & 3 & 2 \\
\hline Total & 5 & 3 & 2 \\
\hline
\end{tabular}


As shown in Table 2, between 13 April and 27 April 1963, The Straits Times published five news articles while both The Sarawak Tribune and Sabah Times published three and two news articles on the military incursion respectively. All of these news articles were in the form of ordinary news reports. It is worth noting that while The Straits Times already published the first news article on the incident on 13 April 1963, The Sarawak Tribune and Sabah Times only began to cover the incident on 16 April 1963 and 15 April 1963 respectively. This was because, as mentioned earlier, both newspapers were not published on 13 and April 1963 due to Good Friday, which was a public holiday in Sarawak and Sabah. Furthermore, The Sarawak Tribune only resumed publication on 16 April 1963.

The Straits Times also published more news articles on the incident compared to the other two newspapers. However, it should be pointed out that The Sarawak Tribune published a two-page news report, which included an indepth eye-witness account recorded by an officer of the Sarawak Government Press, Ivor Kraal ("The raid on Tebedu", The Sarawak Tribune, 16 April 1963, pp. $8,11)$. The Straits Times and Sabah Times also published some details of the same eye-witness account but not as detailed as The Sarawak Tribune. Both newspapers only allocated one page each for the eye-witness account ("Raiding Aza rebels loot shops", The Straits Times, 14 April 1963, p. 1; "Uniformed men raid police post, one killed, two wounded in Sarawak border attack", Sabah Times, 15 April 1963, p. 1). After the military incursion, Kraal went to Tebedu and spoke to members of security forces and residents who witnessed the incident.

The following is Kraal's account on the attack on the police station, published in The Sarawak Tribune:

At about 2 a.m. yesterday [12 April 1963] a band of about 60 men, clad in jungle uniforms and armed with an assortment of weapons, including carbines and automatics, took the track leading to the bazaar from the south.

A teacher of the Chinese school which lies directly behind the bazaar, remembers hearing the barking of dogs and many footsteps.

The Raiders made their way to the police station, then manned by 11 men, and surrounded it, gaining their entry by crawling under the high perimeter fence at several places. 
A solitary light was on in the Charge Room where Corporal John Remek, of Kampong Suba Bau District, was on duty. Everything else was quiet in the still, moonlight night.

The raiders burst into the Charge Room and took John Remek by surprise. This was soon followed by the loud bark of a gun and John Remek fell dead, leaving behind his wife Dohin, and four sons, including twins, to mourn his loss. He was about 30-years-old.

Other raiders went straight to the police quarters and warned the occupants to stay put. More gunshots rang out, and two policemen were wounded - Police Constable Anyua who was shot in the right arm and Corporal Joseph who was wounded in the right ear and right hip.

The attackers asked for the 'Kepala'. One of the policemen recalls that some of the expressions in Malay used by the men were foreign to him - definitely not Sarawak Malay.

Inspector Reginald Chimbon, who is in charge of the station, heard the commotion and tried to leave his quarters. Shots rang out narrowly missing him by which time he was under the house. After firing back, he then leapt into a water tank to take cover and stayed there during the period of the raid.

The raiders in the police station broke the arms' cage and seized the weapons. However, for some reason or other, they left the ammunition almost intact.

It was obvious that one or two had stripped to do this, for they left their uniforms behind, and with them, a personal booklet and several copies of photographs of men in officers' uniforms of the Tentera National Kalimantan Udara; left behind also were "TNKU and BAT.-X" metal badges. Why they were so careless in leaving these things behind is still a mystery. Deliberately careless? ("The raid on Tebedu", The Sarawak Tribune, 16 April 1963, p. 8)

The Straits Times also published the details of the raid as follows but did not mention that the account was recorded by Kraal: 
Uniforms of Azahari's Tentera Nasional Kalimantan Utara were found in Tebedu police station after yesterday's [12 April 1963] attack by 60 armed men.

The raiders came to Tebedu from a track going south to the Indonesian border.

A teacher at the Chinese school in Tebedu said today that at 2 a.m. he heard the barking of dogs and many people passing his home.

The raiders surrounded the small police station, which was manned by 11 men, and crawled under the high perimeter fence at several places.

A solitary light was on in the charge room where Corporal John Remek of Kampong Suba Bau in the Bau in the Bau District of the First Division, was on duty.

Several raiders ran in and shot Cop Remek dead. Other raiders went to the police quarters and warned the occupants not to move.

More shots were fired, and two policemen were wounded - Constable Anyua was hit in the right arm and Cpl. Joseph in the right ear and right hip.

Inspector Reginald Chimbon, the officer in charge of the station, tried to leave his quarters and was shot at. He leapt into a water tank and stayed there throughout the raid.

The raiders in the police station broke the arms cage and took the weapons, but they did not touch for the ammunition.

Then one or two apparently stripped off their uniforms and left them in the charge room together with a TNKU [Tentera National Kalimantan Udara] rebel instruction booklet and several photographs of TNKU men in officers" uniform. ("Raiding Aza rebels loot shops", The Straits Times, 14 April 1963, p. 1)

The above accounts show that the one published in The Sarawak Tribune is more in-depth. For instance, it included the details of the raiders asking for the 'Kepala', i.e. 'head' in Malay. The account also noted that a policeman did not think the Raiders were Sarawak Malays because he was not familiar with 
"the expressions in Malay used by the men" ("The raid on Tebedu", The Sarawak Tribune, 16 April 1963, p. 8). These details were not reported in The Straits Times and Sabah Times.

Both accounts also mentioned that uniforms of the Tentara Nasional Kalimantan Utara (TNKU), a militia led by Azahari who was the leader of the 1962 Brunei Revolt, were left behind after the raid. TNKU was supported by Indonesia (Farrell, 2010). While the title (i.e. "Raiding Aza rebels loot shops") and the first paragraph of the news article published in The Straits Times show that the reporter believed TNKU conducted the raid, The Sarawak Tribune was more cautious and did not make such a claim. Instead, the account in the newspaper included Kraal's query on the uniforms left, as shown in the last paragraph of the account published in The Sarawak Tribune cited above.

In regard to Sabah Times, the first news article on the raid reproduced part of Kraal's account published in The Straits Times without mentioning Kraal's name. Therefore, it can be said that The Sarawak Tribune's coverage on the raid was more detailed and more objective.

In addition, both The Straits Times and The Sarawak Tribune reported that Indonesian minister and commander-in-chief General Achmad Jani [also known as Ahmad Yani] said he had no idea about the raid on Tebedu and Indonesian army had nothing to do with the raid ("Jani: We have no contact with the rebels", The Straits Times, 17 April 1963, p. 16; “'Indonesian army has no contact with recent raid' Jani", The Sarawak Tribune, 17 April 1963, p. 1). Nevertheless, General Jani emphasised that the army provided full support to the Indonesian government's policy of opposing the formation of Malaysia. In fact, the news article in The Sarawak Tribune noted that according to General Jani, "the Indonesian Government [sic] and the Army [sic] follow the principle of resisting any form of colonialism wherever and whenever it may take form" ("'Indonesian army has no contact with recent raid' Jani", The Sarawak Tribune, 17 April 1963, p. 1). This implied that the Indonesian government perceived the formation of Malaysia as a form of colonialism by the British. Both newspapers referred to Reuter when reporting General Jani's remark. Sabah Times, on the other hand, did not report General Jani's remark.

In addition, two news articles in The Straits Times mentioned that British troops were sent to the Borneo territories following the military incursion on Tebedu ("British troops sent to Borneo", The Straits Times, 18 April 1963, p. 1; "New confidence aim of Sarawak moves", The Straits Times, 19 April 1963, p. 6). This was not mentioned in The Sarawak Tribune and Sabah Times.

Nevertheless, Sabah Times did publish a news article on the Indonesian foreign minister Dr Subandrio's remark after a meeting with the British 
ambassador Andrew Gilchrist, held in Jakarta on 26 April 1963, on the situation along the Borneo frontier ("Borneo border discussed", Sabah Times, 27 April 1963, p. 1). Dr Subandrio declined to answer when asked if the military incursion on Tebedu was discussed in the meeting. Sabah Times referred to Reuter when reporting this issue. Dr Subandrio's remark was not covered in The Straits Times and The Sarawak Tribune.

Based on the above discussion, it can be concluded that The Straits Times and The Sarawak Tribune provided wider coverage on the first major military incursion in Sarawak compared to Sabah Times. It is also worth noting that The Straits Times published more news articles on the incident than The Sarawak Tribune. Nevertheless, as mentioned earlier, The Sarawak Tribune provided in-depth coverage of the incident in a more objective manner.

\section{First Major Military Incursion in Sabah, 29 December 1963}

After three months since the formation of Malaysia, Indonesia began to target Sabah as well and launched substantial attacks on a police post in Kalabakan, which was about 30 miles from Tawau, on December 29, 1963. Eight Malaysian soldiers were killed and 19 wounded. The incursion also resulted in the death of a civilian (Indonesian aggression against Malaysia, Vol 1, 1965, pp. 8-10). Hence, it can be said that the first major military attack on Sabah was more serious than the one on Sarawak eight months before, as the former resulted in more deaths and injuries.

Table 3. Type and Number of Selected News Articles on the First Major Military Incursion on Sabah

\begin{tabular}{|l|c|c|c|}
\hline \multicolumn{1}{|c|}{ Type of news articles } & $\begin{array}{c}\text { The Straits } \\
\text { Times }\end{array}$ & $\begin{array}{c}\text { The } \\
\text { Sarawak } \\
\text { Tribune }\end{array}$ & $\begin{array}{c}\text { Sabah } \\
\text { Times }\end{array}$ \\
\hline Ordinary news report & 14 & 3 & 16 \\
\hline Special report & 2 & 1 & 1 \\
\hline Photo(s) with captions & 0 & 0 & 1 \\
\hline Editorial/Letter to the editor & 2 & 0 & 1 \\
\hline Total & 18 & 4 & 19 \\
\hline
\end{tabular}

It is therefore not surprising that the three selected newspapers provided wider and more extensive coverage on the incident in Sabah. As shown in Table 3, between 31 December 1963 and 30 January 1964, Sabah Times 
published the highest number (19) of news articles related to the raid. These included 16 ordinary news reports, a special report, a photo with short captions and an editorial on the raid. The Straits Times published 18 news articles including two special reports, one editorial and one letter to the editor on the raid. The Sarawak Tribune published only four news articles including a special report related to the incident. It should be noted that the number of news articles on the raid in Sabah published in The Sarawak Tribune was slightly higher than that on the first major military attack on Sarawak eight months ago.

Sabah Times and The Straits Times began to report on the raid in Kalabakan on 31 December 1963 while The Sarawak Tribune published its first news article on the incident on 1 January 1964 (" 8 killed; 19 wounded, fierce encounter 30 miles from Tawau, Indons attack police post", Sabah Times, 31 December 1963, p. 1; "Sabah: Soek's men in open attack", The Straits Times, 31 December 1963, p. 1; “U.N. may be called to intervene: 'Right will triumph'”, The Sarawak Tribune, 1 January 1964, pp. 1-2). The Straits Times referred to UPI (United Press International) while The Sarawak Tribune referred to Reuter when reporting on the raid for the first time. Both newspapers reported that the attack resulted in the death of eight soldiers and one civilian as well as the injury of 19 soldiers and one civilian. However, only Sabah Times and The Sarawak Tribune mentioned that "two Indonesians were killed and one captured" on the day of the raid ("8 killed; 19 wounded, fierce encounter 30 miles from Tawau, Indons attack police post", Sabah Times, 31 December 1963, p. 1; “U.N. may be called to intervene: 'Right will triumph", The Sarawak Tribune, 1 January 1964, p. 2).

Both Sabah Times and The Straits Times reported that the Malaysian government offered $\$ 1,000$ (Malaysian dollar) to each wounded soldier ("Tunku's surprise visit", Sabah Times, 6 January 1964, p. 1; "Tunku at the hospital”, Sabah Times, 6 January 1964, p. 1; “\$24,000 to relatives of dead soldiers", The Straits Times, 4 January 1964, p. 9). However, the same news report in The Straits Times also mentioned that the government also offered a total of $\$ 24,000$ to the next-of-kin of the eight soldiers who were killed during the raid. These details were not covered in The Sarawak Tribune.

Nevertheless, Sabah Times covered a few issues related to the raid that was not reported in the other two newspapers. For instance, a news report in Sabah Times on 9 January 1964 mentioned that the Minister for Communication and Works, Dato Khoo Siak Chiew, visited Hong Kong and told a group of Sabahan students studying there "not to be perturbed by the recently reported incidents in Tawau, especially the treacherous Indonesian incursion into 
Kalabakan" ("Indonesia will not declare war on Malaysia", Sabah Times, 9 January 1964, p. 7). Dato Khoo assured the students that Indonesia would not have the courage to declare war on Malaysia because Australia, Britain and New Zealand had given their full support to the country. On 30 January 1964, the newspaper also reported that three of the wounded soldiers "conveyed their heartful thanks to the people of Sabah for their kindness and gifts" ("A big thank you from the soldiers to Sabahans", Sabah Times, 30 January 1964, p. 7).

It is also worth looking at the editorial and a letter to the editor published in The Straits Times as well as the editorial of Sabah Times on the military incursion in Kalabakan. The editorial published in The Straits Times on 1 January 1964 pointed out that the raid on Kalabakan marked "a new phase of 'confrontation'" ("The Tawau warning", The Straits Times, 1 January 1964, p. 8). The editorial also noted that "[t]he scale of this attack, the casualties suffered by the Malaysian security forces and the sensitiveness of the Tawau area combine to make this outrage easily the most serious of all the Borneo border incidents since Malaysia was formed". The editorial remarked that although the Indonesian government might deny that the raid was conducted by its army and claim that the raiders were volunteers who had nothing to do with the Indonesian government, there was "every indication that Indonesian soldiers at least were in charge as they have been in other border affrays". The editorial also mentioned that the Indonesian government had admitted training and arming the guerrillas from Brunei, Sarawak and Sabah. Hence, the role of Indonesia in the raid on Kalabakan was highly speculated. The editorial also urged the Malaysian government to request armed intervention from the United Nations (UN) since "Tawau is a real danger point because access is easy and among a relatively large population there is an Indonesian community of some 7,000 people".

The Straits Times also published a letter from a reader with an initial "K. T. H." on 8 January 1964. The reader urged Malaysia to "manifest its will to survive and to remain free or else it will be the beginning of the end" (K. T. H., "Right will triumph...", The Straits Times, 8 January 1964, p. 8). The reader also reminded Indonesians involved in the Confrontation that Malaysians would not "appease the aggressors".

The editorial published in Sabah Times on 6 January 1964 made a similar remark on the role of the Indonesian government in the raid:

The Indonesian leaders claim that only volunteers are taking part in these incursions, but there is ample evidence that Indonesian soldiers 
are with them to stiffen their aggressiveness. In any case, we find it hard to believe that volunteers are capable of flying military aircraft even if they were allowed to do so. ("Editorial", Sabah Times, 6 January 1964, p. 2)

The editorial additionally mentioned that the Indonesian Communist might also be influencing the Confrontation policy. It called upon the government to keep the people well-informed and to institute "a Home Guard system in the distant villages" as part of the immediate action to deal with the threat.

Although The Sarawak Tribune did not publish many news articles on the incident like The Straits Times and Sabah Times, it is still worth looking at its special report on the incident written by an unnamed special correspondent ("Dateline Sabah", The Sarawak Tribune, 6 January 1964, p. 10). The author pointed out that Tawau was the most important town on the Sabah-Indonesia border and, therefore, "its vicinity was the scene of one of Indonesia's fiercest point of Confrontation". The author also disclosed that there were about 12,000 immigrant Indonesian labourers in Sabah's east coast, where Tawau was located. The immigrant labourers used to be hard-working and law-abiding. However, since the outbreak of the Confrontation, they had been influenced by subversive propaganda and became saboteurs as well as subverts involved in attacking Malaysia.

The above discussion shows that Sabah Times and The Straits Times provided more extensive coverage on the first major military attack on Sabah compared to The Sarawak Tribune. A possible shortcoming of the latter might be its limited manpower.

\section{First Major Military Incursion in Peninsular Malaysia, 17 August 1964}

On 17 August 1964, which was also Indonesia's Independence Day, a group of raiders landed in southwest Johor. The infiltrators comprised not only Indonesians but also Malaysians who were members of the Malayan Communist Party. As noted in Indonesian aggression against Malaysia, Vol. 2 (1965), the landing "was the first major incursion by the Indonesians into West Malaysia and marked a new phase of [the] Confrontation" (p. 1). Nevertheless, the infiltrators were immediately engaged by Malaysian security forces, and some of them were arrested. The hunt for other infiltrators continued for several days.

As shown in Table 4, from 18 to 27 August 1964, The Straits Times published more news articles on the incident than the other two newspapers. 
The total number of news articles in The Straits Times was 32. These included 23 ordinary news reports, two special reports, two photos with short captions, four editorials and one editorial cited from the foreign press. The Sarawak Tribune published 11 news articles including an editorial produced by its editor and another editorial cited from the foreign press. Sabah Times, on the other hand, published ten ordinary news reports on the incident.

Table 4. Type and Number of Selected News Articles on the First Major Military Incursion in Peninsular Malaysia

\begin{tabular}{|l|c|c|c|}
\hline \multicolumn{1}{|c|}{ Type of news articles } & The Straits Times & $\begin{array}{c}\text { The Sarawak } \\
\text { Tribune }\end{array}$ & $\begin{array}{c}\text { Sabah } \\
\text { Times }\end{array}$ \\
\hline Ordinary news report & 23 & 8 & 10 \\
\hline Special report & 2 & 0 & 0 \\
\hline Photo(s) with captions & 2 & 1 & 0 \\
\hline Editorial from the & 1 & 1 & 0 \\
\hline $\begin{array}{l}\text { Editorial cited } \\
\text { foreign press }\end{array}$ & 1 & 11 & 0 \\
\hline Total & 32 & 10 \\
\hline
\end{tabular}

All three newspapers published their first batch of news articles on the military incursion on the same day, i.e.18 August 1964 ("Mop-up goes on, landings in Johore", The Straits Times, 18 August 1964, pp. 1, 20; "Indon infiltrators make secret landing at Pontian", The Sarawak Tribune, 18 August 1964, p. 1; "14 terrorists captured, Indonesian landings", Sabah Times, 18 August 1964, p. 1). However, The Straits Times's news report was covered in more detail, as it also included an illustration showing the location where the infiltrators were spotted by villagers and the location of the mopping operation conducted by security forces.

Those news articles also mentioned that one Malaysian soldier was wounded during the clash. Having said that, there was a discrepancy in the number of captured infiltrators reported in the three newspapers - both The Straits Times and The Sarawak Tribune reported that 16 infiltrators were captured while Sabah Times quoted a smaller number, i.e. 14. Sabah Times later updated the number to 16 in a news report on 19 August 1964 ("Mopping-up operations, two Indons killed", Sabah Times, 19 August 1964, p. 1).

The three newspapers also reported that a Malaysian soldier who was seriously injured passed away in a hospital on 19 August 1964 ("Third Indonesian killed: Malaysian corporal dies of his wounds", The Straits Times, 21 August 1964, p. 1; "Another terrorist killed", The Sarawak Tribune, 21 August 
1964, p. 1; "Fighting continues, Malaysian killed", Sabah Times, 21 August 1964, p. 1). While the news report in The Straits Times was written by its journalist in Johor, both The Sarawak Tribune and Sabah Times referred to Reuter when reporting this incident.

Following the military incursion, Malaysian Prime Minister Tunku Abdul Rahman remarked that he believed one of the objectives of the Indonesian guerrillas who landed in Johor was to assassinate Malaysian leaders. This was reported in The Straits Times and Sabah Times but not in The Sarawak Tribune ("Indons desperate', orders to kill”, The Straits Times, 21 August 1964, p. 1; "Fighting continues: Malaysian killed", Sabah Times, 21 August 1964, p. 1). Unlike the news report in The Straits Times, which was written by its own journalist, the one published in Sabah Times was reproduced from Reuter.

Nevertheless, it is worth noting that in reporting on the knowledge and reaction of Indonesians on the raid on Johor, The Sarawak Tribune and Sabah Times gave a slightly detailed account compared to The Straits Times. The Sarawak Tribune and Sabah Times mentioned that Indonesians generally had no idea of the raid because the local press in Indonesia did not cover the incident. During the Confrontation, the Indonesian government forbade its citizens from listening to Malaysian radio channels. Only those who defied the Indonesian government's order and listened to Radio Malaysia knew of the incident ("Two terrorists killed and several more captured, hunt continues", The Sarawak Tribune, 19 August 1964, p. 1; "Subandrio denies knowledge of Indon landings in Malaya", Sabah Times, 19 August 1964, p. 1). Sabah Times even noted that Indonesians "were wrapped up in their Independence Day celebrations and the local press did not carry stories on the landings" ("Subandrio denies knowledge of Indon landings in Malaya", Sabah Times, 19 August 1964, p. 1). Conversely, The Straits Times only reported that "Indonesians were generally unaware of the Monday [17 August 1964] morning landings in Johore by their forces" ("Johore landings: Subandrio is silent", The Straits Times, 19 August 1964 , p. 1). All the newspapers referred to Reuter when reporting on this issue.

It should be noted that some villagers in Pontian, Johor, cooperated with security forces in securing the capture of the infiltrators by giving them information of the infiltrators. The Malaysian government offered them cash awards. This was reported in all three newspapers ("8-year-old Karim gets cash award for aiding in raiders' capture", The Straits Times, 21 August 1964, pp. 1, 20; "Dato Sardon warns", The Sarawak Tribune, 22 August 1964, p. 1; "Aussies to be used? Tunku's problem", Sabah Times, 22 August 1964, p. 1). The Straits Times and Sabah Times also mentioned that the recipients included an 
eight-year-old boy known as Karim Bin Haroon and that the cash awards ranged from $\$ 100$ to $\$ 1,500$. These details were not reported in The Sarawak Tribune. Again, the news report published in The Straits Times was written by its own journalist while the ones published in the other two newspapers were reproduced from Reuter.

In fact, the news report in The Straits Times gave a very detailed account of the eight-year-old boy:

This is Karim's story:

"I was fishing with my uncle, Inche Latiff bin Bidin, just off the mouth of Sungei Sanglang at 6 a.m. on Monday [17 August 1964] when we saw three motorboats approaching us.

"It was still dark, and we could not see properly who the people in the boats were.

"We thought they were the usual fishermen with whom we are familiar.

"The three boats headed directly towards us and came alongside our small boat.

"We were very shocked and very frightened when the people in the boats pointed guns at us. In the three boats were about 40 men, including some Chinese and some Malays.

"All of them were in the uniforms of soldiers. We also saw haversacks in their boats.

"At gunpoint, they asked us to show them a place where they could land safely without being seen. If we did not comply, they said they would kill both my uncle and I, as they said this, they waved their guns.

"So we led them up the Sungei Sanglang. After travelling about 100 yards, they ordered us to stop. They moored to the side and alighted on the swampy bank.

\section{'Ordered'}

["]After all of them had landed with their belongings and guns, they ordered us to tow their three motor-boats back to the sea from where they had come.

"We were also told 'let the boats drift in the sea.' 
"We obeyed and towed their boats back to the sea. We noticed the vessels carried strange licence plates.

"The first boat had the licence number POF 304 written in bold letters. The second licence number was 48 . The third boat, however, had no licence plate.

"It then dawned on us that these boats could have come from Indonesia.

"So my uncle and I hurriedly rowed our boat south along the coast, with three boats trailing behind us, to Pontian Besar.

"There we handed the three boats to the Marine Police. We also told the authorities of those strangers who had come in these boats.

"We were later taken to the Pontian Kechil police station where we lodged a report. We also pointed out to police the actual spot where the strangers had left their boats." ("8-year-old Karim gets cash award for aiding in raiders' capture", The Straits Times, 21 August 1964, pp. 1, 20)

Although Sabah Times's news report also included the story of the young boy, it was brief and not in the boy's words:

He [Karim] told reporters he and his uncle were out at sea fishing shortly before dawn on Monday morning last when three boatloads of armed men approached.

\section{GUNPOINT}

They were forced at gunpoint to lead the men, about 40 strong, to a river inlet, after which they were released and told to let the boats drift and forget what they had seen.

Instead, they towed the boats to the nearby town of Pontian Besar and informed the police. ("Aussies to be used? Tunku's problem", Sabah Times, 22 August 1964, p. 1)

Although the account in Sabah Times was brief, the account specifically mentioned the armed men told the boy and his uncle to "forget what they had seen" after released. This, on the other hand, was not reported in The Straits Times. The reason for this might probably be due to different sources both newspapers referred to when reporting the incident.

The Straits Times also covered a few other important issues related to the military incursion in Johor that was not reported in The Sarawak Tribune 
and Sabah Times. For instance, on 23 and 24 August 1964, it reported that a few Malaysians were charged under the Internal Security Act (ISA) of Malaysia for possessing arms and consorting with Indonesian infiltrators ("18 in court on arms charge", The Straits Times, 23 August 1964, p. 1; "16 more on arms, consort charges are held", The Straits Times, 24 August 1964, p. 6).

The newspaper also reported that according to the chairperson of the Kelantan State Alliance (the Alliance was the ruling coalition of Malaysia at that time), Dato Nik Ahmad Kamil, there were some Kelantanese who were happy over the landings of Indonesian armed men in Johor ("Where people were happy over the landings by Indons", The Straits Times, 22 August 1964, p. 5). Dato Nik even disclosed that those Kelantanese included some "educated and intellectual people". He spoke about the issue during a delegate's conference at the Kota Bharu division of (Kelantan's capital) United Malays National Organisation (UMNO), which was the major member party in the Alliance, the ruling coalition at that time. He warned the delegates to be watchful for such people. Although Dato Nik did not elaborate much on the background of those Kelantanese who supported Indonesia, it is probable that they were the members or supporters of the Malayan Communist Party because the infiltrators in Johor comprised a few members of the Communist Party.

The Straits Times and The Sarawak Tribune also covered the Daily Mail's view on the Johor landings. The Daily Mail was an English-language newspaper published and widely circulated in the United Kingdom. Both The Straits Times and The Sarawak Tribune mentioned that the Daily Mail in its editorial complained about the world press's lack of concern over the raid on Johor. In other words, most of the press in other parts of the world rarely mentioned the incident. While The Straits Times mentioned the Daily Mail's view in its editorial on 22 August 1964, The Sarawak Tribune reproduced part of the Daily Mail's editorial in one of its news reports with the term "Daily Mail" included in the title ("Shocked by Pontian", The Straits Times, 22 August 1964, p. 10; "Daily Mail: 'Lack of concern over Johore landings'”, The Sarawak Tribune, 22 August 1964, p. 8). This was not reported in Sabah Times.

Lastly, it should be noted that an editorial in The Sarawak Tribune on 20 August 1964 complained that many people in Sarawak did not receive the message from Deputy Prime Minister Tun Abdul Razak regarding the Johor landings relayed by Radio Malaysia Sarawak due to poor reception. The editorial remarked that the problem "could have been avoided if local stations were informed of the intended broadcast and be instructed to arrange for either a recording or a relay (the telephone is always handy for such urgent 
instructions)" ("Closer co-ordination", The Sarawak Tribune, 20 August 1964, p. 2). It further elaborated that.

...the Borneo States exist as well as part of the country and nation and who share the same destiny. The move to expand and strengthen the structure and organisation of the State's broadcasting and information services is more than welcomed but equally of vital importance is the need for closer coordination." ("Closer co-ordination", The Sarawak Tribune, 20 August 1964, p. 2)

The message of the editorial implies that the newspaper and its readers in Sarawak were very concerned about the situation in Johor, although the raid did not happen in Sarawak. Hence, the relatively less extensive reporting on the incident by The Sarawak Tribune, as compared to The Straits Times, was probably due to limited manpower rather than the lack of concern of the newspaper and its readers about the situation in Peninsular Malaysia.

\section{Conclusion}

Based on the findings of this study, it can be said that The Straits Times generally provided more extensive coverage on the first major military incursions on Sarawak and Peninsular Malaysia compared to The Sarawak Tribune and Sabah Times. In regard to the first major military raid on Sabah, it was Sabah Times that provided the most extensive coverage on the incident. This was probably due to limited manpower and financial strength of the two newspapers published in Sarawak and Sabah and not the lack of concern of both newspapers and their readers of the situation in the other localities of the country. Indeed, the findings suggest that readers of the three newspapers were very much concerned about the military incursions in the different localities of Malaysia during the Confrontation.

It is also worth noting that while both The Straits Times and The Sarawak Tribune reported extensively on the first major military incursion on Sarawak, the coverage in The Sarawak Tribune was more objective than The Straits Times.

Some limitations of this study should be noted. First, as we specifically selected English-language newspapers and not newspapers of other languages such as Chinese, Malay, Tamil, Kadazanese or Ibanese, the findings only reflect the concerns of readers who could read English and belonged to middle and upper classes in urban areas. In other words, the findings cannot be generalised to include the other newspapers in Malaysia and their readers. It 
would be useful for future studies to examine the perspectives of newspapers in other languages on the first major military incursions in Sarawak, Sabah and Peninsular Malaysia. Secondly, the research did not cover the perspectives and coverage of subsequent military incursions in the three localities. Hence, it is impossible to determine if there were changes in the perspectives and coverage of the selected newspapers on the Confrontation throughout 1963-1966.

However, this study does possess a methodological strength. It is the first qualitative examination of Malaysian English-language newspapers' coverage on the major military incursions on different localities in Malaysia during the Confrontation. A qualitative analysis also allowed for a more indepth investigation of the coverage of English-language newspapers based in different localities, thus reflecting the readers' concerns of major military incursions around the country during the Confrontation. In addition, the findings also reflect the different financial and manpower strength of the selected newspapers in covering the incident.

\section{Acknowledgements}

The authors are grateful to Haziqah Binti Mohd. Yusof, who assisted during the library and archival research, from April 2016 to April 2017, and from August 2017 to October 2017.

\section{Disclosure Statement}

No potential conflict of interest was reported by the authors.

\section{Funding}

This work was supported by the University of Malaya under Grant Number BK029-2016.

\section{References}

Anderson, J. W. (2006, 31 January). Cartoons of prophet met with outrage. Washington Post. Retrieved 23 January 2017, from http://www.washingtonpost.com/wpdyn/content/article/2006/01/30/AR2006013001316.htm 
Barlocco, F. (2014). Identity and the state in Malaysia. Abingdon: Routledge.

Corporate history. (n.d.). The New Straits Times Press (Malaysia)'s website.

Retrieved January 23, 2017, from http://www.nstp.com.my/corporatehistory/

Farrell, B. P. (2010). What do they want, and how can we respond? Commonwealth intelligence and confrontation with Indonesia, 1963. In M. H. Murfett (Ed.), Imponderable but not inevitable: Warfare in the 20th century (pp. 73-106). Santa Barbara: Praeger.

Harun Abdul Majid. (2007). Rebellion in Brunei: The 1962 revolt, imperialism, confrontation and oil. London: I. B. Tauris.

Indonesian aggression against Malaysia, Vol. 1. (1965). Kuala Lumpur: Acting Government Printer.

Indonesian aggression against Malaysia, Vol. 2. (1965). Kuala Lumpur: Acting Government Printer.

Jones, M. (2002). Conflict and confrontation in South East Asia, 1961-1965: Britain, the United States, Indonesia and the creation of Malaysia. Cambridge: Cambridge University Press.

Mackie, J. A. C. (1974). Konfrontasi: The Indonesia-Malaysia dispute 1963-1966. Kuala Lumpur: Oxford University Press.

Muhammad Fauzi Mohd. Rosidi. (2013/13). Utusan Melayu: Kajian terhadap isu Konfrontasi Malaysia-Indonesia, 1963-1966 [Utusan Melayu: A study on the issue of Malaysia-Indonesia Confrontation, 1963-1966]. Unpublished undergraduate academic exercise, Department of History, Faculty of Arts and Social Sciences, University of Malaya, Kuala Lumpur.

Nik Anuar Nik Mahmud. (2009). Konfrontasi Malaysia Indonesia [The MalaysiaIndonesia Confrontation]. Bangi: Penerbit Universiti Kebangsaan Malaysia.

North Borneo News and Sabah Times.

Poulgrain, G. (2014). The genesis of Konfrontasi: Malaysia, Brunei and Indonesia, 1945-1965. Petaling Jaya: Strategic Information and Research Development Centre.

Profile (n.d.). New Sabah Times. Retrieved 1 July 2017, from http://www.newsabahtimes.com.my/nstweb/profile

S'wak oldest daily returns to newsstand after ban. (2010, 19 May). Malaysiakini.

Retrieved $23 \quad$ January 2017, from

http://www.malaysiakini.com/news/132238

Sarawak Tribune suspended indefinitely. (2006, 10 February). The Sun. Retrieved 23 January 2017, from http://www.thesundaily.my/node/175107

The Sarawak Tribune. 
The Straits Times.

The Straits Times. (2016, 28 February). National Library Board Singapore's website. $\quad$ Retrieved 23 January 2017 from http://eresources.nlb.gov.sg/infopedia/articles/SIP_2016-0229_133820.html

Thien, T. (2004, 4 November). Sarawak English dailies may downsize. Malaysiakini. $\quad$ Retrieved 23 January 2017, from http://www.malaysiakini.com/news/31226

Thien, T. (2006, 9 February). Paper started by Teochew businessmen. Malaysiakini. $\quad$ Retrieved 23 January 2017, from http://www.malaysiakini.com/news/46683

Tribune is the oldest paper in Sarawak. (2006, 10 February). The Star. Retrieved 23

http://www.thestar.com.my/news/nation/2006/02/10/tribune-is-theoldest-paper-in-sarawak/ 